\title{
The Determinants of International Student Movement into Thailand: Push and Pull Factors
}

\author{
Sujinda Chemsripong \\ Faculty of Business, Economics and Communication, Naresuan University, Phitsanulok, Thailand \\ Email: sujindac@hotmail.com
}

How to cite this paper: Chemsripong, S. (2019) The Determinants of International Student Movement into Thailand: Push and Pull Factors. Theoretical Economics Letters, 9, 2785-2799. https://doi.org/10.4236/tel.2019.98175

Received: August 21, 2019

Accepted: November 30, 2019

Published: December 3, 2019

Copyright $\odot 2019$ by author(s) and Scientific Research Publishing Inc. This work is licensed under the Creative Commons Attribution International License (CC BY 4.0).

http://creativecommons.org/licenses/by/4.0/ (c) (i) Open Access

\begin{abstract}
This research aims to analyze the determinants of international student movements in higher education in Thailand using a regression model of the international student movement. The push and pull factors will apply with data access from 141 home countries, according to the number of all international students who studied in Thailand in 2017. Multiple regression equations by using weighted least squares regression have been applied to solve the problem of variance stability of error terms, and the result of the hypotheses test may cause statistical bias. Even though the variables are continuity interval range and normal distribution under classical assumption as the traditional linear model, there is no relationship between the independent variables and has no problem crossing time mobility (autocorrelation) of the model that uses cross section data by using data in 2017. Research results suggest that population of the home country, distance between the home and host countries and enrollment have a significant influence in international student mobility.
\end{abstract}

\section{Keywords}

Educational Trade in Service, Mobility, International Students, Thailand

\section{Introduction}

Students studying abroad have become the main manpower demand of many homecountries. Business education services trade refers to the business of moving students across countries, known as international studies or education without borders [1] that is very important because it generates high income for exporting countries [2]. For example, the United States' first rank as the leader of education service export country in the world had earned the U.S. around US $\$ 11$ billion in 2004 [3]. Australia is the 4th global ranked in service trade's coun- 
try, and generating over AUD $\$ 4.2$ billion of revenue from the educational business [4]. Combining with the globalization and liberalization in the service sector under GATT agreement article [5], the educational services business expanded due to increased convenience, more international trade and more investment. Result in the economic expansion was that students across the country around 1.8 million people in 2000 expected add up to 7.2 million people in 2025 [3] [6]. As a result, many countries are now paying more attention to the movement of international students.

Better understanding of other countries' culture and languages has become their greatest advantage and engaged in global economy trend. Thailand is now paying attention to the movement of international students because this sector, including all levels of education service, generated more than 2.6 billion Bath in 2020 on market value. The biggest contributors are higher education, with a value of over 3000 million baht per year. The international sector has around 12 percent average growth rate per year [7], and the Thai government is looking to position "Thailand as the hub of Asian education service" for two reasons: First, create import substitution for Thai students abroad. By reducing 50 percent of Thai students who study abroad to move back to a local program, expected target of 50,000 people each year, will help reduce the outflow of foreign currency of Thailand of more than 1000 million baht per year. The statistics of Thai students who study abroad dropped from 6492 people in the year 2007 to 2736 people, or almost 50 percent in the year 2019. The number of 43.27 percent is going to study in England, and 32.71 percent study in USA. In the other hand, international students had increased from 11,785 in 2013 to 20,150 people in 2017. However, the number of international students studying in Thailand is still low when compared with the main exporter countries, such as America, England, Australia, and other countries in Europe. Second, Thailand will increase revenue from educational services business in higher education about 20 percent from foreign student revenue, approximately 3000 million baht per year [8]. By designing the target market group of Asian countries including Cambodia, Laos, Myanmar, Chinese (include Taiwan), Japan, Korea, Nepal, Bangladesh, Bhutan and India [9].

Although, there are a few numbers, only 4.85 percent, coming to study in Thailand in the year 2017. The number of international students between 2013-2017 increased 16 percent (from 11,785 students to 20,150 students) or increased average 2000 student each year. Those students interested come to study in private university in Thailand, namely Assumption University, with the highest number of 2673 students in 2017, following by Chang RAI Rajabhad University (CRRU), Chulalongkorn University (CU), Huachiew Chalermprakiet University (HCU) Kasem Bundit University (KBU), Mae FAH Luang University (MFU), Mahidol University etc. [10]. The four major groups of International students come to study in Thailand during the academic year 2013-2017 are: 1) neighboring countries: namely Myanmar, Laos, Viet Nam, and Cambodia 2) countries in Asia include Japan, China, Korea and Indonesia, Malaysia 3) coun- 
tries in South Asia, such as Nepal, Bangladesh, Bhutan, South Pakistan and India 4) others such as France, German. Among these students, students from China are the highest number studying in Thailand as 8231 students in 2017 increased from 4116 students in 1976. There are 2550 students from Myanmar and students from Cambodia are 1055 students in 2017, respectively. The share of international students in different countries can be illustrated by following graph in Figure 1.

As, higher education markets differ across countries in many respects. Each country has different environments such as regulation, policy, economic, social and population, these will affect the educational service management, standard of education, and the elimination of trade barriers in services to reach the educational goals and can compete with other countries which have different factors and context [6]; [11]; [12]. This research, therefore, is interested in studying how Thailand can attract and increase the number of international students from abroad. So, what key factors determine the movement of international students moving into higher education in Thailand? The objective of research is to analyze the factors that determine the movement of international students moves to study in Thailand. The article is organized as follows. The dominating theories of the mobility and the previous literature on movement influencing factors are reviewed in Section 2. In the subsequent Section 3 is described forms the basis for the hypotheses with conceptual framework of the research. Section 4 presents the econometric model and the methodology used in the analyses, while Section 5 the data is described and some descriptive statistics presented. Section 6 reports the regression results. The paper concludes by a discussion and summary of the finding, and also suggestions some avenues for research in Section 7.

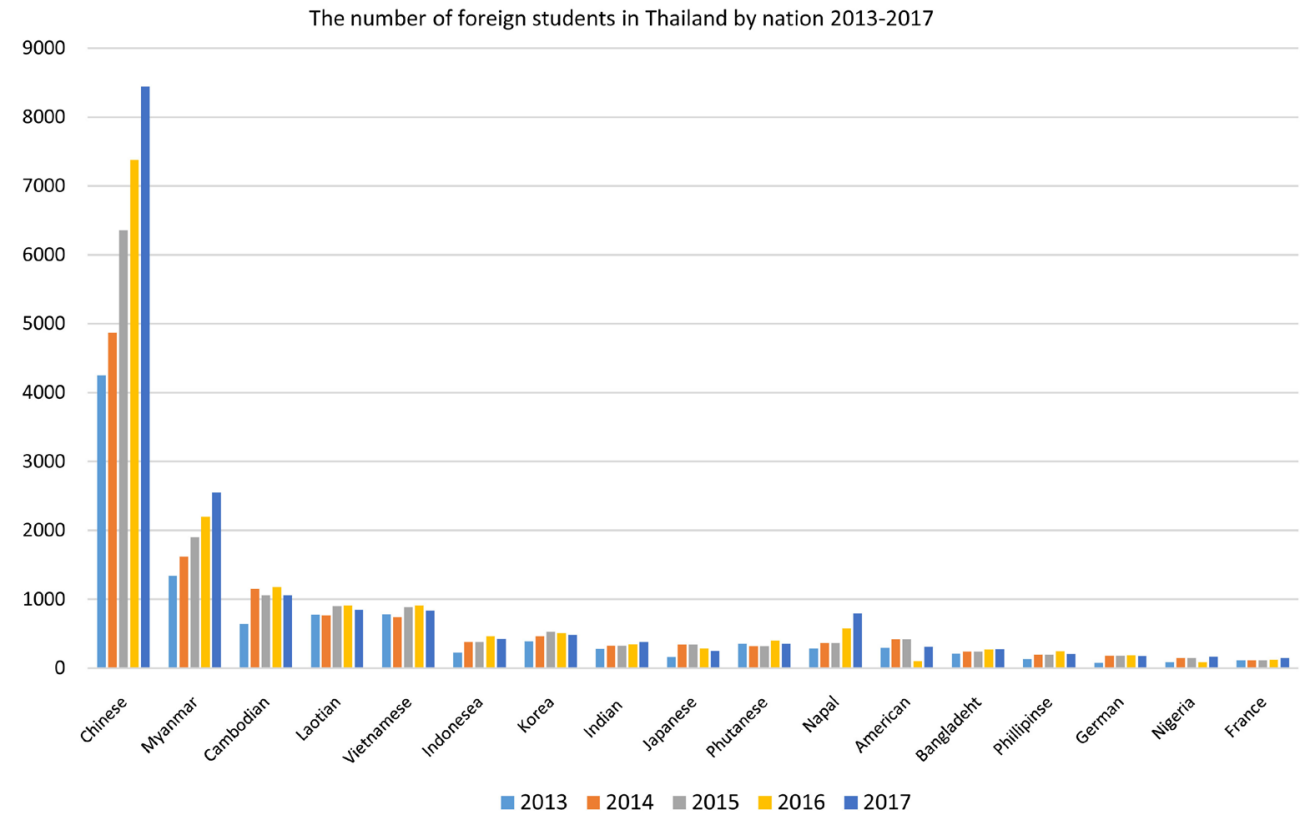

Figure 1. Distribution of foreign students in tertitary education in Thailand, by country of origin, 2013-2017. Source: Higher Education Information Center, (2018). 


\section{Theoretical Basis and Empirical Studies}

According to education is special service products which received consumer satisfaction directly and classified as an investment for student in terms of financial such as gain more income and non-financial benefit such as gain more opportunities in career and work for a good job in the future, social networking and the society acceptance, etc. but to study in a foreign country are more complicate than study in the country. Because not only consider the internal factors of students then but also consider the limitation of external environment such as distance, language, the difference cost of living, study fees, entrance criteria, quality of the program, cost of living and conditions of the visa from the home country, etc. However, many research study on the issue of studying abroad from educational and cultural perspectives. Only few research has been pay attention to the factors that influence international student mobility. This section will review the major theories of the mobility and the previous literature on movement influencing factors.

The influencing factors of migration, which are the original and destination country environment, obstacles and demographic factors, had developed by [13] so called the push-pull model. [13] also described that movement is depended on size or area difference, population density, and obstacles. Later, the push-pull model has been applied for international student mobility by [14] cited by [15]. Therefore, this model is formed to analysis how supply and demand relationships [15]. Through this model, some reasons of studying abroad were pushed by unfavorable conditions in their home countries, while others were pulled by scholarships and other opportunities in countries of destination. The pull factors of the host countries included many factors, such as research institutions; social, economic and political environments and international classmates [16] cited by [15]. While, the push factors influencing the movement of demand for study abroad consists of the following factors.

First, internal factors include characteristics of those who want to study in a foreign country, such as gender, age, nationality, language, and academic performance [17]. The literature on foreign student movements also emphases the level of language proficiency [18] cultural and linguistic factors as affecting student choice. [29] argues instead that foreign students as a proportion of total domestic enrolments tend to be low when the language of instruction is not widely used, suggesting that the influence of language is a little more indirect. [1] point out that the effects of trade barriers will be tested by reference to explicit information about the regulatory policy regimes in each country e.g. [19] or worth of mouth of study abroad of persons in the family, friends, advisors and representatives of education, will be the key influences. Level of referrals or personal recommendations that the study destination receives from parents, relatives, friends and other gatekeepers prior to making the final decision. The support of the parents in the study foreign e.g. [20], [21] belief or understanding of international friends and the culture of other countries by [22] and believe in the 
opportunity for jobs and a higher income classes in the country, etc. influence of more advanced study overseas [23].

Second, external factors in home country include education factors mentioned by [18], [24] as the lack of higher education in the home country, the quality of education in the home country is low and the perception of degree from abroad in home country in labor market. Additional, pull factors such as institution's reputation for quality, in the student's home country was influenced by the availability of information about the potential destination country and the ease with which students could obtain the information, market profile, range of courses, alliances or coalitions, offshore teaching programs, staff expertise, degree of innovation, use of information technology, resource, size of the alumni base and promotion and marketing efforts (e.g. the use of agents and advertising) make a particular institution more attractive than its competitors [25]. The quality of reputation is likely to remain the most important factor influencing study destination choice. The study climate in destination country, as well as, its physical climate and lifestyle. Social links, which related to whether a student has family or friends living in the destination country and whether family and friends have studied there previously [25].

The political factors include the proportion or percentage of government expenditure in the region to study and gross domestic product (GDP), the importance of education of home country government is likely to remain the most important factor influencing study destination choice. As well as economic factors include home country's income and, the level of economic wealth, the priority placed on education by government of the home country and the availability of educational opportunities in the home country is likely to remain the most important factor influencing study destination choice [26]. Average income in the home country as the level of economic success in home country adjusting by [26] and the economic factor, represented by the price or cost in education such as education fees, travel expenses, the education opportunities available in home country and the expected benefits of studying abroad as the principle flow drivers of international student in home country were found by [24]. The correlation between economic prosperity in sending countries and the volume of international student flows was found negative that the greater educational opportunity counteracts the effect of improved GDP per capita. The correlation between the size of the host nation and the sending nation's economies was found a positive result [26]. These economic factors have an influence on the high number of international student flow, because economic factors represent higher educational opportunities than the impact of per domestic product (GDP) [20]. [27] develops equation to test of student choice involving optimization of earnings, and uses GDP per capita as a proxy for the quality of education, whereas the effect of GDP per capita and the quality of education enter separately. For example, the economic link between the home and host country raised by [28] that host national political interest in home country through foreign assistance or cultural links and host nation support of 
international students via scholarships or assistance present the forecast of foreign student enrolments in which population and income as only two behavioral determinants.

In addition, [21] found that expenditure on education is one of the key factors to be considered for decision of international students to study abroad.

The cost issues, including the cost of fee, living expense, travel costs and social costs, such as crime, safety and racial discrimination. The presence of students from the student's country (social cost) and the availability or part time work (financial costs) also formed part of this factor. [30]; [31] and [32] found that tuition fee is one key factor, that could affect the decision, that is to study higher education institutions whose tuition fees are not very high, the option is important in decision making. [33] found that low tuition is one of the key reasons to choose in higher education study, as well as the cost of study in university, lower than nominal wages will expect increase learning decisions [13], [18] tuition fees do not greatly influence student choices. The study of [34] points that increase in tuition fees and living costs in Australia did not impact the flow of foreign students perhaps place higher value on other perceived benefits, such as program relevance, qualifications and career pathways. Some literature e.g. [29] and [21] has suggested that distance (or geographic remoteness) affects the demand for higher education whereas the above discussion emphasizes its role in determining the cost of successfully applying screening tests. [21] mentioned that geographic proximity, which related to the geographic (and time) proximity of the potential destination country to the student's country.

However, according to the study of [35] found that the factors which have effect on students' intentions to study abroad could be accounted as followed: economic factors (29\%), educational factors (27\%), student's personal factors (15\%), social factors (13\%), cultural factors (9\%), and political factors (7\%). Most of these factors were external forces which had the influence on students' choices; however personal factors affected the students' choices at the same time. Since there is no definitive consensus on the correct set of determinants, this study chooses some variables which will be influencing to students' mobility. By using econometric methods, the aim of this study is to examine the factors that may have statistically and economically significant effects on student mobility.

\section{Hypotheses/Assumption of the Research}

In order to find the determinants behind international student mobility, a framework categorizing these various rationales into economic and non-economic factors can be highlighted [36]. This research has developed a model of foreign student movement, which consists of independent variables or the movement of foreign students come from varies countries to Thailand. According to education services business are different from other service businesses, such as banking or insurance, because it operates through the movement of consumers, the students. In this case, the exporters are the educational institute or university who provided educational service, and the international students are therefore, 
consumers or importers. The income of the educational business is represented through each student movement, whether it's movement through institute between areas, individual educators, or movement across countries based on the barriers of trade. This research has developed the movements of international students came up from a review of the independent variables or movement of International students from different countries in Thailand as follows:

1) Population size of the home country becomes an important variable that impacts the movement of international students. Country with a large population would have more demand for secondary education, in which they might not be able to be fulfilled internally and larger number of student chooses to study abroad. Therefore, the relationship between the population amount is directly proportionate to the movement of international students [24]; [26]; [27] [28] and [36]. This became our hypothesis:

H1: Population amount of the home country has positive impact on the movement of international students to the host country.

As for the variables to be used in our model, we deploy the data of the entire population from the home country i.e. [28]. For example, [36] use the number of applicant university in the home country each year, by per scribe that teenage populations are people with age around 18 - 24 years, which are the age range for higher education. The three variables can be the substitute with the variable of the population from home country thus so. This research paper utilize variables based on [24]; [28] due to there should not be any limit to the age group related to education. Population data are from online website [37].

2) Distance between the home and the host country is one important factor in movement of study [1]; [21]; [27]; [29]. The distance, that may relate to both economic factors and cultural proximity of home and host countries, is related with the demand for higher education [29]. It also included the cost and expenses while study. The longer the distance means the lower the application rate, because longer distance may cause higher cost and relate to cultural differences. Distance has relationship with the cultural gap. The differences in cultural gap will attract certain type of students. The more similar cultures make it easier to be involved in the host country. On the other hand, large cultural differences may attract some students to come and study and experience a different culture. Therefore, the relationship between the distance and applications from international students is negative, if the distance between the two countries is larger, the demand will be lower.

H2. Distance between the home country and the destination country has correlation with movements of international students.

For variables in this research, we deploy distance in education, in which the data are from website the new great circle mapper [38].

3) Average income of the home country is one of the factors in international student movements because the income dictated how much one can afford the education. If the home country has higher average, it should mean that the students have the ability to absorb higher education and living cost. On the other 
hand, if the home country has lower average, the ability to afford education might not be there, and there are lower demands [28]. Furthermore, it also depended on the income gap between the origin and the host country. If the gap is too wide, the home country will not be able to afford education at all [39] had suggested smaller GDP gap between both countries. Therefore, our hypothesis becomes:

H3: Average income of the home country is related to the movement of the international students coming from that country.

For the variable to measure the average income from the home country, some research use purchasing power parity (PPP) represent price levels in any two countries, developed by [40]; [41] research from [28] use GDP represent living expense, exchange rate. [27] develops equation to test student choice involving lifetime optimization of earnings. The effect of quality at the destination is non-linear, because as quality goes up, tuition fees go up and eventually the price effect on demand dominates. Furthermore, in his empirical implementation he uses GDP per capita as a proxy for the quality of education, whereas in the above formulation the effect of GDP per capita and the quality of education enter separately.

4) The education quality of home country. [21] focus on the major factor influencing of international choice study abroad and found that reputation and quality of education e.g. quality of teacher educational standards alumni and course of institute is the main factors consider with expenditure on education. and Acceptance of labor markets impact of opportunity to work in the future. From research of [33]; [31] explore factors that affect decision in the study found that the quality and reputation of the Institute, is an important factor in deciding study of students. This factor pushes students to studying abroad if the education quality of home country is low. The result causes increasing movement students from home country to study in host countries, in contrast if the education quality in home country is high, student in home country is not necessary to go to study abroad that has a lower quality. The demand for studying abroad is less. The relationship between the education quality and the student movement is expected to be positive. Like research of [19] [34] [42] [43] [44] [45] and. Therefore, the researcher has set the following assumptions:

H4: The education quality of home country related to the number of foreign students moving from home country.

This research uses the university's world ranking in home country as a measurement to describe the education quality from various countries. University's ranking uses data from [46]. The relationship between the educational quality in home country and the number of foreign student movement will be negative.

5) Government expenditure on higher education (home country support). As the government expenditure on higher education in home country may influence the school quality and quantity. A high level of quality of education has provide the comfortable learning environment, teaching atmosphere, facilities and some financial support as a scholarship for foreign student, all these factors 
may attract international students more interested to study in host country. Higher government expenditure can help to improve education and development. Therefore, the relationship between the government expenditure support of the home country in higher education and the number of movements of the student will be negative [24]; [26]. The assumptions are as follows:

H5: The government expenditure of the home country is associated with the number of foreign students moving from the home country as a proportion of GDP.

This research uses variables of government expenditure ratios per GDP of the home country to explain.

6) A proportion of enrollment in higher education of home country is the number of admission to higher education in home countries, as the ratio of percentage in each group. If the applicant of higher education level in home country is high, the number of international students moves to study in higher education shown as assumption.

H6: A higher proportion of higher education enrollment in the home country related with the number of foreign students moving from the home country as proportion of GDP.

\section{Econometric Model}

This research is a quantitative research to find out the factor of movements from international students coming into Thailand. Model developed based on review literature, theories, data, and research that involved variables used in this study are:

1) Dependent Variables

Exed $=$ The number of foreign students coming into Thai secondary education system.

2) Independent Variables

POPs $=$ The number of population from home country enrolled in host Country.

DIST $=$ The distance from home and host country.

GDPPC $=$ The average income from home country.

WRANK $=$ The quality of higher education in home country.

GEXP = The government support in higher education, as a ratio of GDP, in home country.

GER $=$ The ratio of application for secondary education as the percentage of GDP in home country.

The model of international student movement is

Exed $=($ C, POPs, DIST, GDPPC, WRANK, GEXP, GER $)$

$(+),(-),(+),(+),(-),(+)$.

Model selected by logit model, assumed parameter by maximum likelihood estimation. To test parameters with maximum likelihood, we test with wald test and goodness of fit measure, and analyze the results. 


\section{Data}

This research is a quantitative research, using the number of all international students coming to study in Thailand's data in the year 2017, there are a total of 141 countries, as the dependent variable. Analysis of the independent variables which applied in multiple regression model using the weight least squares technique, (WLS), due to the characteristic of variables are continuity interval range and normal distribution under classical assumption as the traditional linear model. The error terms are normal distribution with constant variance of the model that uses a cross section data by using data in 2017 .

\section{Research Results}

The econometric model is first estimated by ordinary least square estimation. The result of the independent variable's coefficients that we used as factor variable in the movement of international students. Consider the value adjusted R2 for the percentage of variable variance, as described by all independent variables as 47.73 percent statistical value $F=22.081$ at significant level 0.05 . In order to consideration of the effect using the OLS technique found that there are variance stability problems of error term and result of the hypotheses test may statistical bias. Therefore, to solve the problem with estimating a mode applied the estimates model of weighted least squared regression for the second estimation. The result is contained in Table 1 . The result of the independent variable's coefficients that we used as factor variable in the movement of international students, analyzed with SPSS application, is as follows: Consider the value adjusted R2 for the percentage of variable variance, as described by all independent variables as 15.4 percent Statistical value $\mathrm{F}=5.306$ at significant level 0.05 (Consider selecting an independent variable value with a value less than 0.05 is the value that significantly indicates that the selected free variable is used to describe in this model. Considering the significant value less than 0.05 , consider the details in Table 1 to contain.

Table 1. The result of estimate of international student's movement model.

\begin{tabular}{ccccccc}
\hline \multirow{2}{*}{ Model } & \multicolumn{2}{c}{ Unstandardized Coefficients } & Standardized Coefficients & \multirow{2}{*}{$\mathrm{t}$} & Sig. \\
\cline { 2 - 4 } & & $\mathrm{B}$ & Std. Error & Beta & & \\
\hline 1 & (Constant) & 51.660 & 15.184 & & 3.402 & $0.001^{*}$ \\
& POPs & $9.662 \mathrm{E}-7$ & 0.000 & 0.458 & 3.519 & $0.001^{*}$ \\
& DIST & -0.003 & 0.001 & -0.788 & -4.503 & $0.000^{*}$ \\
& GDPPC & $2.607 \mathrm{E}-5$ & 0.000 & 0.036 & 0.215 & 0.830 \\
& WRANK & 0.002 & 0.002 & 0.188 & 1.219 & 0.225 \\
& GEXP & -0.154 & 0.789 & -0.016 & -0.196 & 0.845 \\
& ENROLL & -0.199 & 0.092 & -0.336 & -2.165 & $0.032^{*}$ \\
\hline
\end{tabular}

a. Dependent Variable: STUDENTS; b. Weighted Least Squares Regression Weighted by New Weight; c. Predictors: (Constant), ENROLL, GEXP, POP, WRANK, GDPPC, DIST. $\mathrm{R}^{2}=0.190 \mathrm{~F}=5.306$ Sig. $=0.000$; Adjusted $\mathrm{R}^{2}=0.154 \mathrm{~N}=142 ; \mathrm{SEE}=0.954 \mathrm{SS}=152.671$. 
From Table 1 can be written in the form of a regression equation. As follows:

ExEd $=51.660+0.0000009662 \mathrm{POP}^{\star}-0.003 \mathrm{DIST}^{\star}+0.00002607 \mathrm{GDPPC}+$ 0.002 WRANK -0.154 GEXP + 0.199 ENROLL.

Adjusted $\mathrm{R}^{2}=0.154, \mathrm{n}=142 *$ Significant at $95 \%$ confidence interval.

The results show that even though the low adjusted $\mathrm{R}$ squared, can explaining independent variable is not much causes of dependent variable changes but $F$ statistic shows that the independent variables could analyze to describe the dependent variables. The results significant variable influencing foreign student study abroad are population of the home country, distance between the home and host countries and enrollment have a significant influence on international student mobility.

\section{Conclusions}

The objective of this study was to analyze the determinants of international student movements in higher education in Thailand by using a model of the international student movement with external variables. This research tests many independent variables in the movement of international students, i.e. the population size of home country, distance between home and host country, average income, quality of education, cost of education, and secondary education application ratio. The study was found that every independent variable in the model has some relationships with other variables, following our hypothesis. But only three independent variables become significant in the movement of international students. These variables are significant in both two different estimation results. As, the most significant variable in the movement is the population size, the distance between the two countries and the ratio of student enrollment.

First, the population number of the home country, contributes positively to the movement. The sign of this variable is positive and t value is significant in the all estimated model. This outcome is an obviously higher proportion of population; more students choose to study abroad. A large amount of population will lead to lack of education resources seriously. The supply of education cannot satisfy the increasing demand. In consequence, many students have to look for the chance of study in other countries. More students will bring about high pressure on employment. International students could look for other opportunities in host country. The population size as a factor of the movement is consistent with the paper [28] [36] stated that the relationship between the population size of host country has impact on the movement of international students in Thailand.

Second, the distance between the home and the host country, contributes negatively to the same movement. The coefficient is negative in the all estimated model which implies that the longer distance between host and source country the lower will the enrollment of international students from the source country be. The expensive travel cost and cultural differences are the main factors to block international student mobility. This finding is consistent with [1] [27] that 
stated geographical factors are important variables in dictating the movement of international students, also consistent with [20] that also stated geographical distance and time zone contributed to the movement of international students, where there might be family and friend relationship already established in the host country. [29] said that distance is a factor in secondary education because it dictated the cost of education. The same result with negative results that the longer distance between host and source country the lower will the enrollment of international students from the source country be. The expensive travel cost and cultural differences are main factors to block international student mobility. This variable is significant in both two different estimation results.

Third, the enrollment ratio of application for secondary education as the percentage of GDP in home country, contributes the positive significance to the international student movement which implied that the higher enrollment ratio in home country the higher enrollment of international student from home country be. This finding is consistent with [28] present a forecasting model of foreign student enrolments in which population and income are the only two behavioral determinants. [29] argues instead that foreign students as a proportion of total domestic enrolments tend to be low when the language of instruction is not widely used, suggesting that the influence of language is a little more indirect.

\section{Suggestion}

As the output side of education resource, host countries need does more activities to attract more students from all over the world. Based on the results, distance becames the significance in the movement of international students. Therefore, Thailand should set a clear strategy of potential international students that sees Thailand as a desirable education destination. For example, Thailand's neighboring countries such as Myanmar, Cambodia, Laos, and Vietnam are only a short distance away, with small cultural gap, and attractive cost compared to Europe and the United State. On the other hand, there is potential that countries with large populations like China, India, Bangladesh, and Pakistan could be interested in international education in Thailand. Furthermore, host country government should provide more support from both fiscal and policy. From fiscal aspect, government should expense more proportion of GDP on education. On one hand, it could enhance the quality of education. The education institution could buy better equipment and engage more talent people as teachers and researchers. On the other hand, government supports could be favorable to provide high scholarship and soon. From the policy stand point, host country should have more positive attitude to international students. For example, extension visa policy. Secondly, education institutions of host countries should raise their education quality in order to have a competitive state. It has relationship with how the graduate certification from the host country will be approved. Creating a better studying environment for international students is quite useful to show their advantages. If host country could provide perfect career planning and job opportunity to the students, it must receive a great deal of 
attention in the field of studying abroad.

\section{Conflicts of Interest}

The author declares no conflicts of interest regarding the publication of this paper.

\section{References}

[1] Raychaudhuri, A. and De, P. (2007) Assessing Barriers to Trade in Education Services in Developing Asia-Pacific Countries: An Empirical Exercise. Asia Pacific Research and Training Network on Trade Working Paper Series, No. 34, 1-57.

[2] WTO (2001) Guide to the GATS: An Overview of Issues for Further Liberalization of Trade in Services. World Trade Organization, Kluwer Law International, The Hague.

[3] Böhm, A., et al. (2004) Forecasting International Student Mobility: A UK Perspective. British Council, London.

[4] Böhm, A., Davis, D., Meares, D. and Pearce, D. (2002) Global Student Mobility 2025: Forecasts of The Global Demand for International Higher Education. Working Paper IDP Education Australia.

[5] WTO (2015) Service Sectoral Classification List. https://www.wto.org/english/tratop e/serv e/serv sectors e.htm

[6] Knight, J. (2006) Cross-Border Education: Conceptual Confusion and Data Deficits. Perspectives in Education, 24, 15-28.

[7] Choklamloet, M. (2017) The General Director of International Trade Promotion. The Ministry of Commerce, Presentation in the Seminar on Creating Business Opportunities for Thai International Education to the World, Bangkok, 20 June 2017.

[8] Department of Export Promotion (2017) International Education Service Business. https://www.ditp.go.th/contents attach/210415/210415.pdf

[9] Department of Trade Negotiations (2018) Educational Service Year 2018. 1-31.

[10] Higher Education Center (HEC) (2018) Office of the Higher Education Commission. Statistics of International Student in High Education.

[11] OECD (2004) Internationalization and Trade in Higher Education: Opportunities and Challenges, Organization for Economic Cooperation and Development, Paris.

[12] UNESCO-OECD (2005) Guidelines for Quality Provision in Cross-Border Higher Education, UNESCO and OECD, Paris.

[13] Lee, E.S. (1966) A Theory of Migration. Demography, 3, 47-57. https://doi.org/10.2307/2060063

[14] Altbach, P.G. (1998) Comparative Higher Education: Knowledge, the University, and Development. Hong Kong: Comparative Education Research Centre, The University of Hong Kong, Hong Kong, 240.

[15] Li, M. and Mary, B. (2007) Cross-Border Flows of Students for Higher Education: Push-Pull Factors and Motivations of Mainland Chinese Students in Hong Kong and Macau. Higher Education, 53, 791-818. https://doi.org/10.1007/s10734-005-5423-3

[16] Davis, T. (1995) Flows of International Students: Trends and Issues. International Higher Education, 1, 2-4. https://doi.org/10.6017/ihe.1995.1.6167

[17] Miller, C.D. and Byrnes, P.J. (2001) To Achieve or Not to Achieve: A 
Self-Regulation Perspective on Adolescents' Academic Decision Making. Journal of Educational Psychology, 93, 677-685. https://doi.org/10.1037/0022-0663.93.4.677

[18] Becker, R. and Kolster, R. (2012) International Student Recruitment: Policies and Developments in Selected Countries. Netherlands Organization for International Cooperation in Higher Education (Nuffic), The Hague.

[19] Knight, J. (2005) Cross-Border Education: An Analytical Framework for Program and Provider Mobility. In: Smart, J. and Tierney, W., Eds., Higher Education: Handbook of Theory and Research, Volume 21, Springer, Dordrecht, 30.

[20] Mazzarol, T., Kemp, S. and Savery, L. (1997) International Students Who Choose not to Study in Australia: An Examination of Taiwan and Indonesia, Australian International Education Foundation, Canberra.

[21] Mazzarol, T. and Soutar, G. (2001) The Global Market for Higher Education. Sustainable Competitive Strategies for the New Millennium. Edward Elgar, London, UK.

[22] Pettibone, S. (2001) A Study of the Value Beliefs and Attitude of Students at an International High School. Doctoral Dissertation, Education, Boston University, Boston, MA.

[23] Palika, B. (2003) The Effect of Study Abroad and Personality on Employment and Earnings in Maxico. Dissertation Abstract International. No. DA.3118052.

[24] Agarwal, V. and Winkler, D. (1985) Foreign Demand for United States Higher Education: A Study of Developing Countries in the Eastern Hemisphere. Economic Development and Cultural Change, 33, 623-644. https://doi.org/10.1086/451482

[25] Mazzarol, T.W. (1998) Critical Success Factors for International Education Marketing. International Journal of Education Management, 12, 163-175. https://doi.org/10.1108/09513549810220623

[26] McMahon, M. (1992) Higher Education in a World Market: An Historical Look at Global Context of International Study. Higher Education, 24, 465-482. https://doi.org/10.1007/BF00137243

[27] Kim, J. (1998) Economic Analysis of Foreign Education and Students Abroad. Journal of Development Economics, 56, 337-365. https://doi.org/10.1016/S0304-3878(98)00069-8

[28] Banks, M., Olsen, A. and Pearce, D. (2007) Global Student Mobility: An Australian Perspective Five Years On. IDP Education, Adelaide.

[29] Wattanavichien, S. (2006) An Analysis of International Undergraduate Programs in Thailand. Doctoral Dissertation, Education, Chulalongkorn University, Bangkok, Thailand.

[30] Jones, E. (2002) Factors that Influence College Choice for African Student. Union Institute and University.

[31] Dennard, E. (2000) The Influence of Psychosocial Factor on College Choice and Subsequence Student Satisfaction with College Experiences. Dissertation Abstracts International.

[32] McLeod, M. (1997) Marketing Survey of PJC Students, Pensacola Junior College. Florida Office of Institution Research and Effectiveness.

[33] Follari M. (2004) Comparative Costs of Higher Education for International Students 2004. IDP Education Australia.

[34] Tremblay, K. (2001) Student Mobility Between and Towards OECD Countries: A Comparative Analysis. OECD International Mobility of Higher Skilled, OECD, Paris, 39-67. 
[35] Dong, L. and Jing, W. (2008) The Determinants of International Student Mobility-An Empirical Study on U.S. Data Economics Master Thesis.

[36] Naidoo, R. (2007) Higher Education As A Global Commodity: The Perils and Promises for Developing Countries. The Observatory on Borderless Higher Education, UK, 1-19.

[37] World Bank (2019) World Development Indicators. http://datatopics.worldbank.org/world-development-indicators/themes/people.html

[38] The New Great Circle Mapper (2019) http://gc.kls2.com

[39] Freeman, Y. and Freeman, D. (1992) Whole Language for Second Learners. Portsmouth. NH Heinemann.

[40] Gustav, C., (1921) The World's Monetary Problems; Two Memoranda. London, Constable.

[41] Pakko, M.R. and Pollard, P.S. (2003) Burgernomics: A Big Mac ${ }^{\mathrm{TM}}$ Guide to Purchasing Power Parity. Federal Reserve Bank of St. Louis Review, 85, 9-28. https://doi.org/10.20955/r.85.9-28

[42] Chapman, R. (1979) Pricing Policy and the College Choice Process. Research in Higher Education, 10, 37-57. https://doi.org/10.1007/BF00977498

[43] Murphy-Lejeune, E. (2002) Student Mobility and Narrative in Europe: The New Strangers. Routledge, London.

[44] Tierney, M. (1983) Student College Choice Sets: Towards an Empirical Characterization. Research in Higher Education, 18, 271-284. https://doi.org/10.1007/BF00979600

[45] Shackleton, J. (2003) Opening up Trade in Higher Education: A Role for the GATS? World Economics, 4, 55-77.

[46] Webmetrics (2019) Ranking of World University. http://www.webometrics.info/en 